CRISTINA VIEIRA DA SILVA ${ }^{1}$

DOI: 10.15290/CR.2019.24.1.05

ESEPF/Research Centre on Child Studies,

University of Minho, Portugal

ORCID ID: 0000-0003-2248-0829

ÍRIS SUSANA PIRES PEREIRA ${ }^{2}$

Research Centre in Education,

Institute of Education,

University of Minho, Portugal

ORCID ID: 0000-0003-0647-2319

ISABEL SEBASTIÃO ${ }^{3}$

Centre of Linguistics

of the University of Porto,

University of Porto, Portugal

ORCID ID: 0000-0003-0896-4384

\title{
Portuguese teachers' perceptions of grammar teaching
}

\begin{abstract}
The teaching of grammar, as envisaged in the official curriculum, has been identified as challenging for many Portuguese teachers. In this paper, we present a study conducted with the aim of characterizing primary and middle school teachers' perceptions about their own grammar teaching, utilizing Shulman's model (1987) as adapted by Grossman (1990). We carried out a collective case study, using a questionnaire survey ( $\mathrm{n}=200$ teachers) to determine the importance teachers attach to teaching grammar, the degree of perceived adequacy of their knowledge and the difficulties they identify in this area of their teaching. The results reveal that teachers' perceptions are shaped by multiple decisive factors including content knowledge, pedagogical content knowledge, knowledge of the curricula and general educational knowledge. Based on these findings, we advocate the need to rethink how teachers are trained and to (re) create awareness about the complexity of knowledge in grammar teaching and its role in effective student learning.
\end{abstract}

Keywords: grammar teaching, grammatical content knowledge, pedagogical content knowledge, curricular knowledge.

1 Address for correspondence: Departamento de Formação de Professores, Escola Superior de Educação de Paula Frassinetti, R. Gil Vicente, 138-140, 4000-255 Porto, Portugal. E-mail: cristina.vieira@esepf.pt

2 Address for correspondence: Departamento de Estudos Integrados em Literacia, Didática e Supervisão, Instituto da Educação, Universidade do Minho, Campus de Gualtar, 4710-057 Braga, Portugal. E-mail: iris@ie.uminho.pt

3 Address for correspondence: Centro de Linguística da Universidade do Porto, Faculdade de Letras da Universidade do Porto. Via Panorâmica, s/n, 4150 - 564 Porto, Portugal. E-mail: isabel.sebastiao@hotmail.com 


\section{Introduction}

The teaching of grammar has been considered one of the most debated curricular issues of the past half-century in the literacy teaching field (see Milian 2014: 43) and in the last two decades, it has been the subject of some debate in Portugal.

One major factor underpinning recent discussion about grammar teaching and learning is acknowledgement of the relatively little pedagogical attention it has received from teachers, a situation that also seems to be the case in other countries (Boivin et al. 2018). During the 1960s and 70 s, the dominant grammar teaching methodology in Portuguese classes focused on memorization and prescriptive teaching, following a similar trend especially present in francophone education (see Boivin 2018) which strongly influenced Portuguese education models. However, by the 1990s, a radically new and decisive approach towards grammar had emerged, by which grammar as a subject became practically absent from mother tongue classes or was conceived in a way that undervalued the need to understand it, following linguistic trends without any validation or recognition in educational terms and, in particular, communicative approaches based on foreign language teaching methodologies (see Duarte 1986, 1998). Grammar quickly came to be seen as something useless, quite often disregarded by teachers but also by educational policy, as could be seen in the lack of a common metalanguage for grammar or in the nonexistent quality control of educational grammar books. This situation still prevailed in the early 2000s, as highlighted by Duarte (2000):

Hidden behind the excuse that 'students do not like grammar', being influenced by the dominant communicative approach in the teaching of foreign languages or being aware of the arising insecurity due to the lack of grammatical nomenclature approved for all primary and secondary schools and also to the general lack of quality of the pedagogical grammars available on the market, Portuguese language teachers spend less time and give less importance to grammar, reducing grammatical reflection in their classes. (Duarte 2000: 55, our translation)

As a consequence, in the 2000s, the value of grammar teaching in the curricula and in teaching practices became the subject of a lively debate in Portugal, involving linguists, teacher trainers, teachers and academics from other fields in the humanities. The high point of this debate was perhaps the controversy generated by the political implementation of a Linguistic Terminology for Elementary and Secondary Education (TLEBS), adopted on a trial basis in 2005, and subsequently revised and replaced by a Terminological Dictionary, which is now official and available online (http://dt.dge.mec.pt/). Important as this development might have been in the effort to stabilize grammar education, grammar teaching and learning actually continued to be a field of political dispute. In fact, only two years after the beginning of a new Program for Portuguese language teaching in Basic Education (Reis 2009) and due to a political change, in 2012 a new Ministry of Education and Science approved the implementation of the Curriculum Goals for the Portuguese Language (Buescu et al. 2012), a set of benchmarks intended to identify "essential learning un- 
dertaken by students [...] highlighting what in the programs should be the paramount object of teaching" (Despacho 2011). Different design and organization approaches in drawing up these two documents (Reis 2009; Buescu et al. 2012), which also have different didactic perspectives, resulted in the coexistence of two official curriculum guidelines, namely a Program on the one hand, and Curriculum goals on the other, whose notorious inconsistencies and differences were publicly exposed on several occasions (in particular, by the Portuguese Teachers Association and the Portuguese Association of Linguistics). Finally, in 2015, the Ministry of Education and Science replaced the 2009 program with the new Program and Curriculum Goals for Portuguese (Buescu et al. 2015). In the present decade, successive curricular changes have therefore resulted in intense curricular instability (see Silva 2015), with teachers being challenged to reflect on and act pedagogically according to guidelines which have likewise not always been uniform with regard to grammar.

Despite these political efforts and although recent official curricula for the Portuguese language have included grammatical knowledge as one of the five skills to be developed, along with reading and writing, listening and speaking, it is commonly recognized, even today, that grammar has come to occupy a minor place in mother tongue language classes when compared to other language skills.

Our study is thus framed within this context, focusing on teachers' perceptions regarding their specific professional knowledge and practice of grammar teaching. Fifteen years after Duarte's (2000) acknowledgement that grammar was the least valued skill in the Portuguese language classroom and now that the accelerated succession of curricular norms concerning grammar education seems finally to be abating, our study seeks to answer the following research question: How is grammar teaching currently perceived by teachers? As is the case in other countries (see Myhill 2018: 18), the body of research on the subject is still weak and fragmented in Portugal and aimed mainly at proving the efficacy of grammar teaching procedures. In contrast, we want to know what teachers think about their grammar education nowadays and also to inquire about why they hold such views, assuming that these beliefs (whether positive or negative) have a significant impact on the way they go about grammar teaching in the classroom (Nespor 1987). It is, therefore, our hope that such feedback can provide valuable information in helping us draw conclusions about possible developments and constraints in the teaching of grammar from the perspectives of teachers themselves.

\section{Teachers' Knowledge Base: a lens to investigate teachers' thinking about grammar teaching}

Our study was generally framed by Shulman's concept of Teachers' Knowledge Base (Shulman 1986, 1987). The particular relevance of Shulman's model is in its understanding that, like any other profession, education requires its professionals to have a specific knowledge set, constituting a Teacher's Knowledge Base, which, once acquired, goes through a lifelong process of systematization and transmission (Shulman 2004). Just as in other areas of teaching, we consider that teachers' knowledge also plays an important role in the way teachers think and act (Roldão 2007) when it comes to grammar teaching. 
Shulman's pioneering work led to the identification of a complex set of knowledge dimensions underpinning teachers' work which until then had often been misunderstood or even ignored. Shulman highlighted the fact that, for teachers, knowing "how to teach" is as important as knowing "what to teach", putting a new emphasis on the knowledge involved in how to teach. In fact, according to Shulman's model, teachers' knowledge is not limited to the knowledge emanating from the scientific discipline that is taught (for instance, linguistics in the case of teaching grammar) but, crucially, involves knowledge about the construction of how students learn. He called such a notion Pedagogical Content Knowledge (PCK), which he conceived as being exclusively specific to teachers. PCK involves the representation and formulation of concepts, didactic techniques and knowledge about what makes concepts difficult to learn and recognition of the prior knowledge students bring to the learning context, which can be either facilitative or dysfunctional for the learning task. Understood as a form of practical knowledge, PCK blends content and pedagogy into an understanding of how particular concepts, problems, or issues are to be organized, represented and adapted to the interests and abilities of learners, and then presented for instruction. As such, PCK is a concept of special interest for us since it identifies a distinctive body of knowledge in teaching grammar.

Shulman's model was further developed by Grossman (1990), who contributed to the establishment of a renewed model of the Teacher's Knowledge Base as can be found in Figure 1. She redefined and structured PCK into four different areas, namely knowledge of the purposes for teaching, knowledge of students' understanding, curriculum knowledge and knowledge of instructional strategies, thus clearly demonstrating the inherent complexity of PCK. Building on Shulman's ideas, Grossman's more refined conceptualization of PCK was given a central role in the teachers' knowledge base, interrelating dynamically with other categories of teachers' knowledge already identified (or at least hinted at) by Shulman, such as Specific Content Knowledge, General Educational Knowledge and Knowledge of the Context.

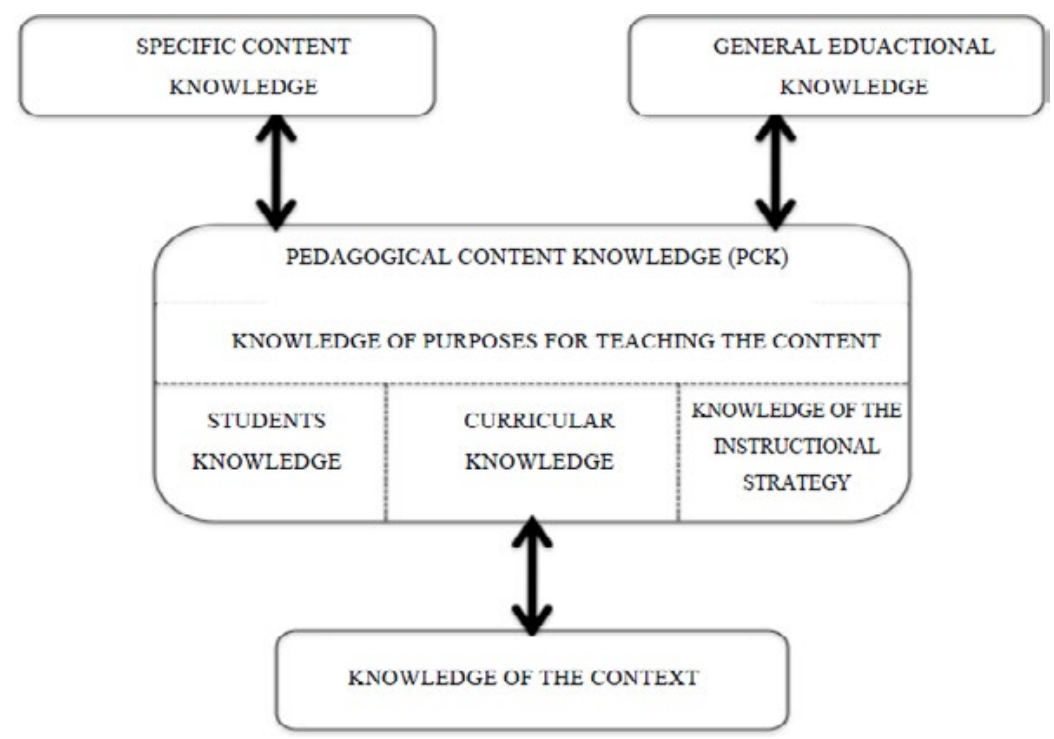

Figure 1. The structure of Teacher's Knowledge Base (Grossman 1990, adapted) 
Following Shulman (1987), several studies have tried to analyze the levels of teachers' knowledge that are involved in specific areas such as mathematics, science and beginning literacy teaching (see Pereira et al. 2015). We have adopted this model in the belief that it would also provide a useful lens when investigating teachers' thinking about grammar teaching. In particular, we consider that teaching grammar involves teachers having specific linguistic knowledge, general educational knowledge, knowledge about the context of teaching and, necessarily, a specific PCK. Our assumption is that the PCK lying at the core of grammar teaching comprises: (i) awareness of the goals of teaching grammar; (ii) knowledge about the concepts, preconceptions, and difficulties students show in learning grammar; (iii) familiarity with contents as specified in the official curriculum; (iv) knowledge of teaching strategies that can adequately reconcile students' specific learning needs with curriculum contents and learning goals. As such, the model in question focuses discussion on the complexity of the knowledge base that underpins teaching grammar, dismissing simplistic notions that might consider such teaching to be merely the transmission of linguistic knowledge. We posit this theoretical lens to be useful when looking into teachers' thinking about grammar teaching.

\section{Research methodology}

We have carried out a collective case study (Stake 2000) to conduct our research. It was undertaken in a context that involved a wide range of primary and middle school teachers from different schools in the north of Portugal, who were participating in a professional development initiative also focusing on grammar teaching. This was an official in-service training course, promoted by the Portuguese Ministry of Education and Science, aimed at developing teachers' understanding of Portuguese Language Curriculum Goals (see above), which they would then be responsible for sharing with their peers, back in their schools. It involved the language teaching coordinators (or the teacher in charge of the curricular area of Portuguese), one per school, from all the primary and middle schools (which in Portugal include students aged up to 12 years old) from the five districts of northern Portugal (Porto, Braga, Viana, Vila Real and Bragança). The in-service program was coordinated by the Faculty of Arts and Humanities of the University of Porto.

From a total of about 250 teachers registered for training, we selected a sample of 200, who were asked, during the initial period that preceded the training sessions, to complete a survey questionnaire that was distributed by hand. The survey questionnaire was the data collection instrument used as it was the most appropriate in terms of the population surveyed; that is, a rather large group of teachers with whom we had only had very brief contact until that moment.

The survey had a bipartite structure, the first part included seven items regarding respondents' personal and professional data, followed by a second part aiming to identify: i) the importance given to and the frequency with which these teachers teach grammar as compared to other linguistic skills, ii) the perceived adequacy of their training in this area, and iii) the difficulties they identify in grammar teaching (whether experienced by themselves as teachers or by their students). This survey contained a total of thirteen items, mostly closed or multiple-choice ques- 
tions using a Likert scale. The questionnaire had been previously validated by a group of teachers not participating in our study. Data collection was conducted in July and September 2013. In this paper, we present and discuss data regarding middle school teachers and, when considered relevant, data from primary school teachers, previously presented and discussed in Silva and Pereira (2014).

The majority of the participants were female (89\%), most of whom were aged between 41 and 60 years old, meaning that most had considerable professional experience, with only a residual number of respondents having been teachers for less than 16 years. As this profile infers, as far as professional status is concerned, the respondents' level of experience parallels the type of school status they held, $93 \%$ of them thus being teachers with permanent tenure. The academic qualifications held by the respondents is consistent with their age profiles: $78 \%$ of respondents had a BA degree; a considerable number of teachers (24\%) had a Master's degree, with only a residual percentage (8\%) of qualified teachers holding postgraduate degrees and $4 \%$, a $\mathrm{PhD}$. On the whole, therefore, our respondents were experienced and qualified teachers, who had witnessed and enacted the unstable curriculum framework briefly mentioned above. We thus had good reasons to believe that they would have meaningful and relevant ideas about their knowledge and teaching of grammar to share with us.

\section{Results and discussion}

The analysis of the collected data revealed strong perceptions among teachers regarding the importance, adequacy and difficulties involved in grammar teaching. From this we have arrived at some important conclusions about the way teachers currently perceive grammar teaching.

\section{On the importance of grammar teaching}

We started by evaluating the relative importance teachers assign to grammar teaching when compared to the other curricular areas of language education: oracy (speaking and oral comprehension), reading and writing skills. When asked to gauge the relative importance of teaching each of these skills and teaching grammar, teachers almost unanimously assigned a high degree of importance to all of them. Reading and writing were identified as being very important by the highest proportion of respondents (100\% and 99\%, respectively); grammar and oracy, meanwhile, were recognized as very important by a smaller proportion of the teachers ( $80 \%$ and $72 \%$, respectively) (see Figure 2). It should be noted that grammar is considered quite important by $20 \%$ of the teachers, and that only oracy is also devalued to the same extent by a similar proportion $(27 \%$ and $1 \%$ of respondents considering it "quite important" or "not very important", respectively). 


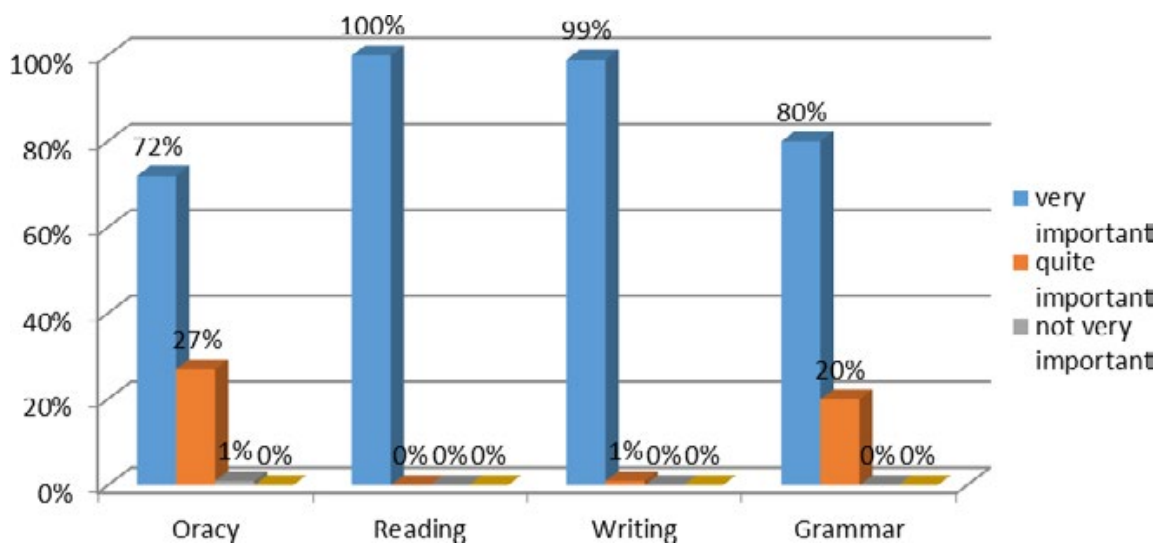

Figure 2. Perceived importance of the different language skills

by middle school teachers

The results of the next item in the questionnaire are in line with the high importance attributed to each of these areas. It assessed teachers' perceptions about the time they devoted to grammar, confirming the valuation patterns identified above (see Figure 3). In particular, it shows that the above-mentioned tendency to devalue grammar and oracy is matched by teachers' perception that they are also the target of less frequent teaching time, with grammar perceived to be addressed "very often" by $72 \%$ and "quite often" by $28 \%$ of the respondents.

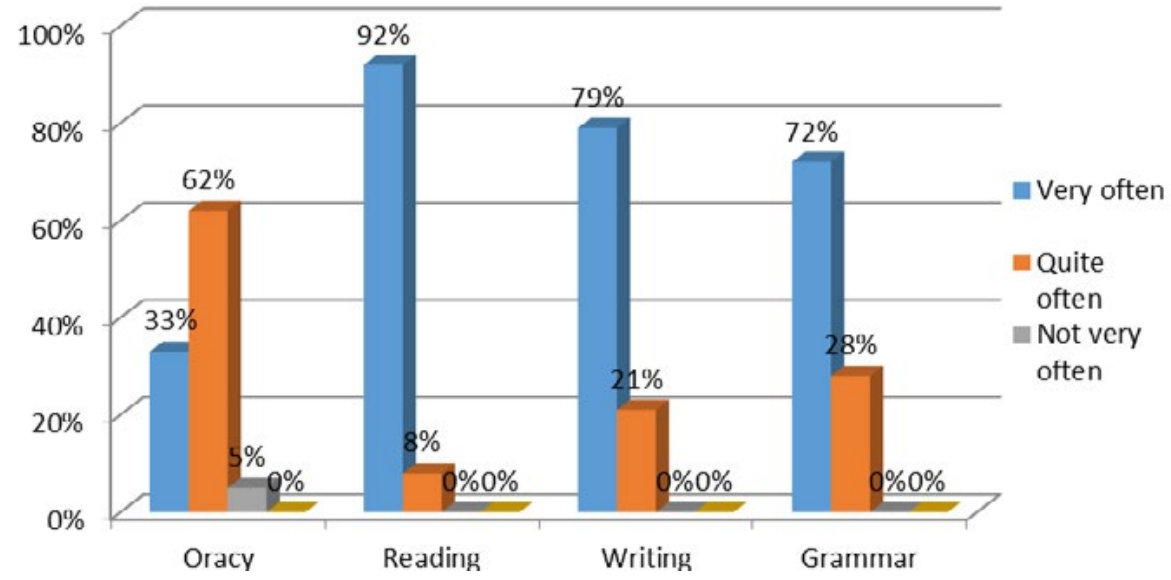

Figure 3. Perceived frequency of grammar-related activities being addressed in the classroom by middle school teachers

By collecting data on the relative importance teachers attribute to grammar teaching and the frequency with which grammar-related activities are being addressed in their classroom, it was our intention to compare these teachers' thinking with the now long-held representation that teachers avoid working on grammar. While the relative undervaluation of grammar teaching is indisputable, it should also be noted that teachers do not consider it to be as unimportant as one might infer from Duarte's (2000) critique, in fact they appear to value it more highly than oracy teaching. We see this as a promising result as far as the current state of grammar teaching is concerned. 


\section{On teachers' specific training in grammar teaching}

Our data show that most of the teachers surveyed consider their training in grammar teaching to have been substantial. While some refer to having constructed such knowledge in their initial training, the majority of those who stated they have had specific training in this area say that it was through an in-service teacher-training context like the one in which they were participating when the data for this study was collected. In fact, following the successive changes in the official curricular guidelines for language teaching that have been introduced in the last two decades in Portugal, a significant effort to implement nationwide continuous training programs has triggered dynamic growth in professional development, including training in grammar teaching. We are referring, specifically, to initiatives such as the (in-service) Portuguese National Education Program (PNEP) between 2007 and 2010 (see Pereira et al. 2015) as well as to the initiatives held apropos the Terminological Dictionary (Costa et al. n/d.), the PPEB (Reis 2009) and the MCPEB (Buescu et al. 2012). Being official teacher-training programs, their purpose has been to involve teachers in reflection on teaching and learning of the Portuguese language, focusing both on linguistic and didactic knowledge, in order to indirectly improve students' results. While our data thus suggest that teachers perceive the importance of such in-service initiatives in terms of their grammar PCK, it is also significant that $39 \%$ of the teachers mentioned not having had any specific training in grammar teaching.

In this context, it made sense for us to analyze data concerning particular teachers' perceptions about the adequacy of their training specifically with regard to grammatical knowledge. Most respondents (70\%) perceived their training as reasonably "suited", the remaining answers being distributed between "much suited" (26\%) or, in contrast, "unsuited" (4\%).

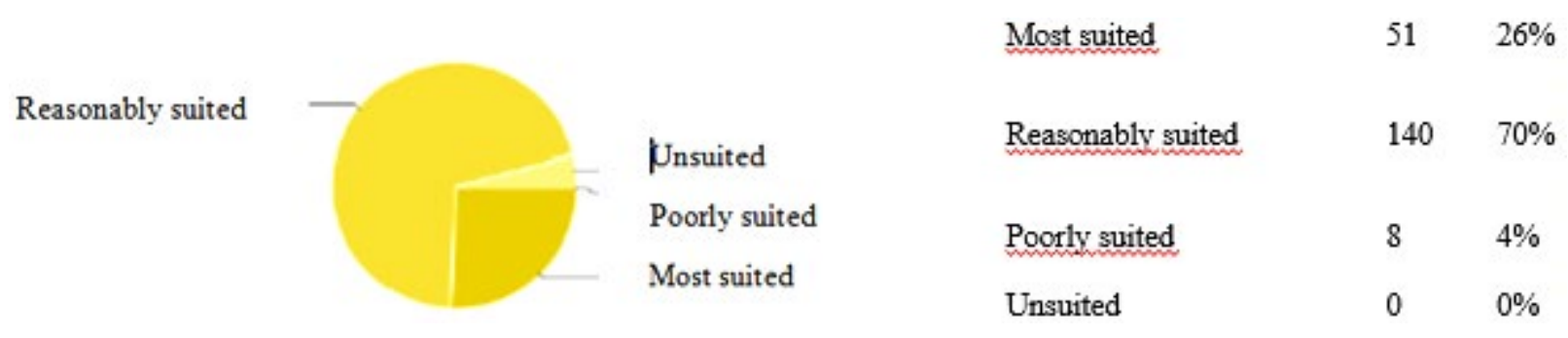

Figure 4. The degree of perceived adequacy regarding teachers' grammatical knowledge

The most significant facts revealed by these data are (i) the diversity of the teachers' perceived adequacy of their grammatical knowledge and (ii) the fact that such adequacy is situated in a space that falls short of the very good level. That is, most of the teachers do not see themselves as having very good grammatical knowledge, which seems even more problematic when we consider the fact that our respondents were selected from the most qualified teachers in their schools to participate in the in-service training which they would subsequently put into practice. Although this lack of confidence is actually not indicative of what kind of knowledge is at stake (general content knowledge or PCK), clarification is provided by the next question, which requested teachers to consider 
the three main difficulties that they face in the teaching of grammar and rank them from the most important to the least important.

\section{On teachers' difficulties in grammar teaching}

The results shown in Figure 5 allow us to infer that teachers do not perceive their content knowledge (about grammar) as being particularly critical since the items targeting grammatical content (in particular, doubts regarding grammar contents) were globally identified as those posing the least difficulties.

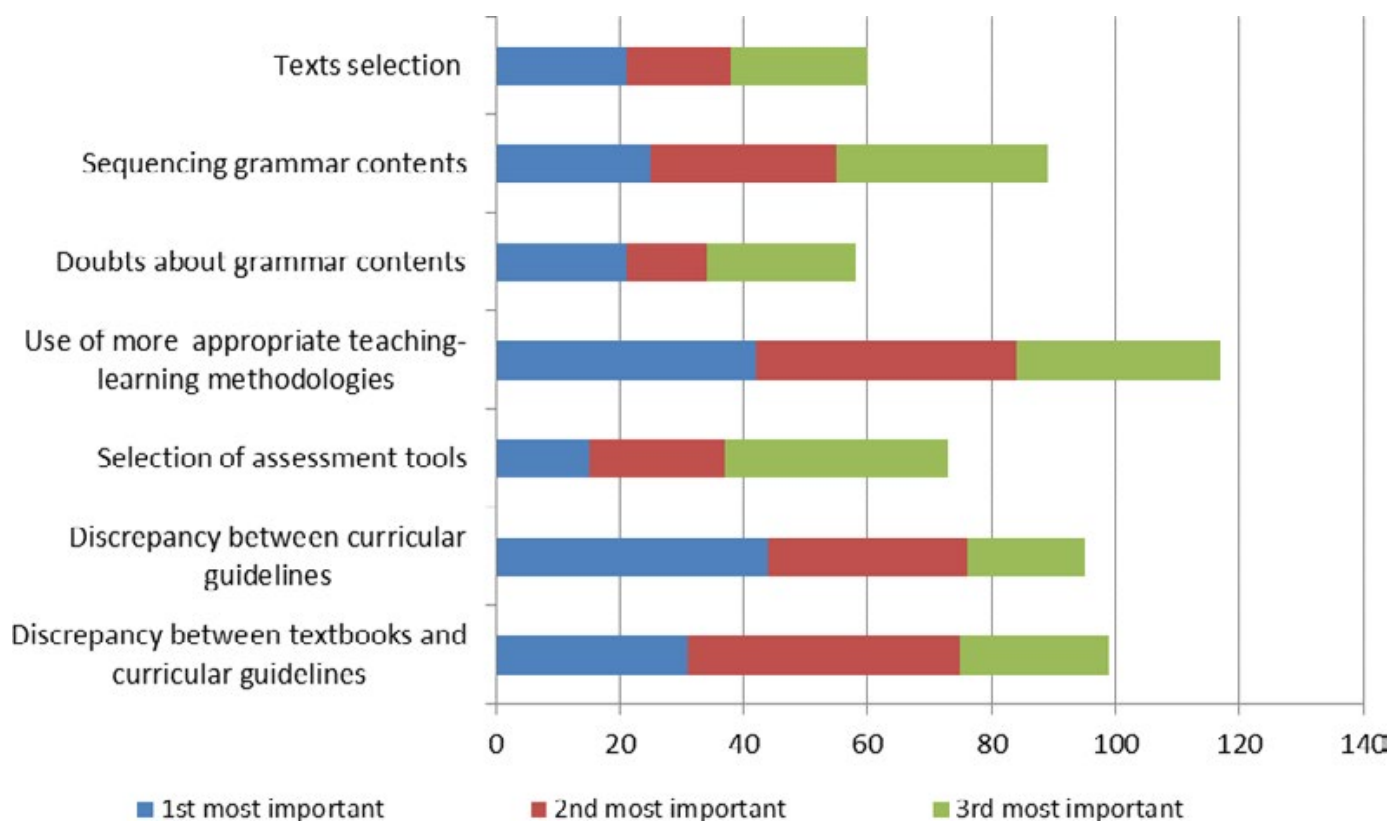

Figure 5. Identification of the three main difficulties experienced

by middle school teachers in grammar teaching

However, the highest rates in the questions associated with PCK, such as use of more appropriate teaching methodologies, selecting texts to address certain grammatical contents, the most appropriate assessment tools or even sequencing grammatical contents, which were perceived by teachers as raising greater difficulties, clearly expose the inadequacy of teachers' PCK. In the Teachers' Knowledge Base model, these items are representative of the 'knowledge of instructional strategies' category. The lack of knowledge that these teachers say they have in this category is generally in line with results from other studies, which point to the difficulty that exists in teachers' development of the strategic knowledge required in order to ensure the necessary didactic transposition (Chevallard 1985; Milian 2014: 49).This is in accordance with Ferreira (2012), whose study of the conceptions and practices of six Portuguese middle school teachers regarding grammar teaching concluded that there was "a predominance of traditional and transmissive methodologies that are characteristic of a deductive or expository approach to grammar" (Ferreira 2012: 115). Moreover, it is also in line with data resulting from a nationwide study conducted by DGIDC (2008: 15), according to which teachers' most frequently adopted strategy in teaching grammar, indicated 
in $90 \%$ of responses, involved "[...] explanation of rules, with exemplification". This same study revealed that alternative strategies involving "...reflection or observation and data manipulation activities" were residual, contrary to what had been assumed in official and normative curricular guidelines such as the CNEB (DEB 2001) and the PPEB (Reis 2009), as well as in research and dissemination documents produced for training purposes. Despite the publication of several examples of grammar workshops and laboratories designed for different levels of schooling, such teaching methodologies incorporating active strategies, have not yet been accommodated into teachers' PCK and, consequently, appear not to be systematically used in their practices.

These results also point to another category of PCK perceived to cause difficulties in grammar teaching. We are referring here to teachers' awareness that the divergences between the terminology found in textbooks and in the official curricular documents or even differences within these documents themselves is also a major source of difficulty. Put another way, instability in curricular knowledge is also perceived to be a source of difficulties in the grammar teaching process. To the best of our knowledge, this dimension of professional knowledge has so far not been discussed in research on grammar teaching in Portugal (see Duarte 2000; Costa 2007; Silva 2008, 2010). On the whole, these results show that although teachers acknowledge the impact of in-service professional learning initiatives, these actions have in fact been inadequate in improving critical areas of their grammar teaching, including PCK.

\section{On students' difficulties in learning grammar}

As a separate item of the questionnaire, we posed some questions with the aim of gaining a more complete view of how teachers perceive the process of teaching and learning grammar. In particular, we asked teachers to identify the three main reasons which, in their view, justify the difficulties experienced by students in grammar learning. Although reasons attributable to PCK (teaching methodologies or materials used and, to a lesser extent, students' lack of skills or previous grammatical knowledge) as well as the level of abstraction of grammar concepts were pointed out by teachers, these were relatively minor, with students' lack of study habits clearly standing out as being the main reason attributed to learning difficulties, both in terms of the total number of responses as well as the proportion identifying it as the most important reason, as shown in Figure 6.

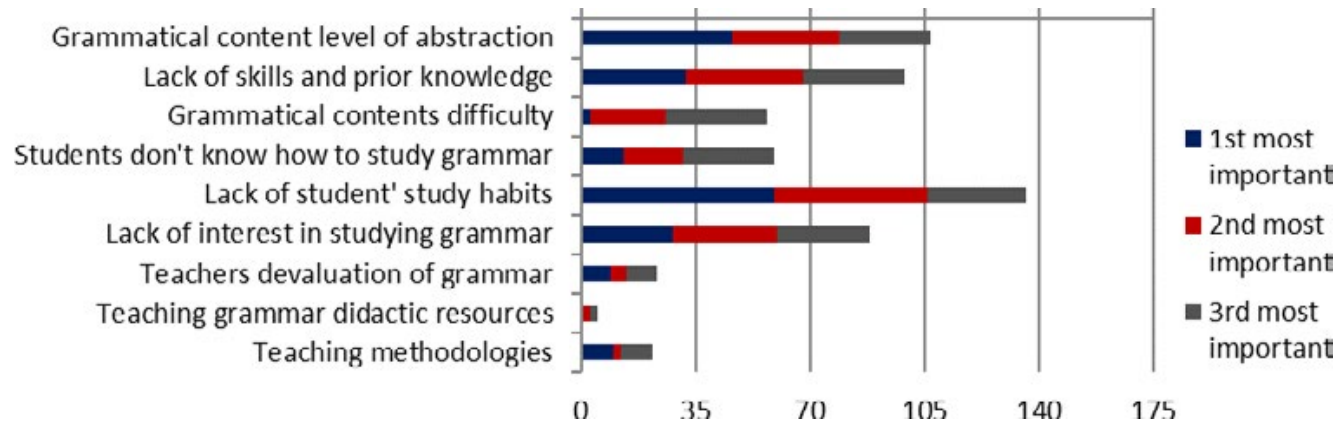

Figure 6. Identification of the three main reasons for difficulties experienced by students in grammar learning, according to Middle School teachers 
While showing teachers' apparent Knowledge of Context concerning their teaching, particularly in relation to students' profiles, the most frequently chosen reason, in fact, reveals the existence of a critical area in these teachers' Knowledge Base which we had not anticipated, namely, the view that students' difficulties arise from the students themselves. The fact that a very sizeable proportion of respondents chose this reason shows that these teachers assume that they themselves are not accountable for their students lack of success and, instead, to a very large extent, consider the students to be solely responsible for the difficulties they face in learning grammar. This indeed echoes Duarte's (2000) claims, which seem not to have changed. It is as if these teachers' perception of their students' difficulties did not trigger them to reflect on the effectiveness of their own practices, in particular regarding their own teaching difficulties, as perceived, assumed and revealed in the former questionnaire item. We interpret this as suggesting a weak General Educational Knowledge among these teachers, in particular regarding a social constructivist understanding, which assumes the existence of a close connection between the activity of teacher and students' learning. On the contrary, we consider that our teachers' thinking may reveal a transmissive view of teaching as a whole, which, as discussed above, is ultimately related to teachers' perceptions about the need to improve their instructional strategies. Evidently, the professional learning and development situations in which they have participated have likewise not been helping these teachers to build such fundamental knowledge in this specific area of grammar teaching.

\section{Primary and middle school teachers' perceptions: the main difference}

A rather different situation was revealed by an earlier study that we had conducted (Silva \& Pereira 2014), whereby we characterized the perceptions of primary school teachers, also responding in the same context of an in-service training event, with regard to their grammar knowledge and teaching. In fact, the approximately 170 primary school teachers involved in that study considered their professional training in Specific Grammar Knowledge to have been insubstantial, indeed perceiving it to be weaker than that of their middle school colleagues. Only $16 \%$ acknowledged that the education they had received in this area had been "very suited", while the majority (68\%) affirmed that the grammar knowledge they had gained was "suited", with 15\% saying that their knowledge was "barely suited". Herein lies the major difference among this group of teachers, which we consider relevant to the present discussion. When asked about the three main difficulties faced in grammar teaching, primary school teachers quite consistently stressed the dimension relating to scientific knowledge (e.g., doubts about grammatical content), together with didactic knowledge (the use of more appropriate teaching-learning methodologies, for example), as shown in Figure 7. 


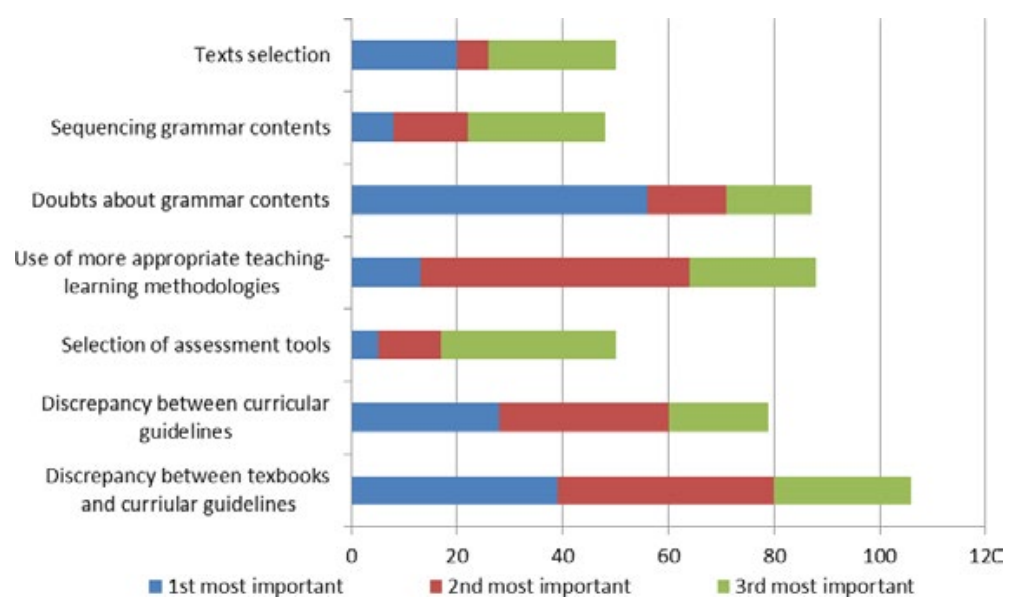

Figure 7. Identification of the three main difficulties experienced by primary school teachers in grammar teaching

Furthermore, when asked to justify students' difficulties related to grammatical learning, the level of abstraction of grammar contents as well as the difficulty of grammar contents are perceived to be two of the most important reasons from primary school teachers' perspective (see Figure 8).

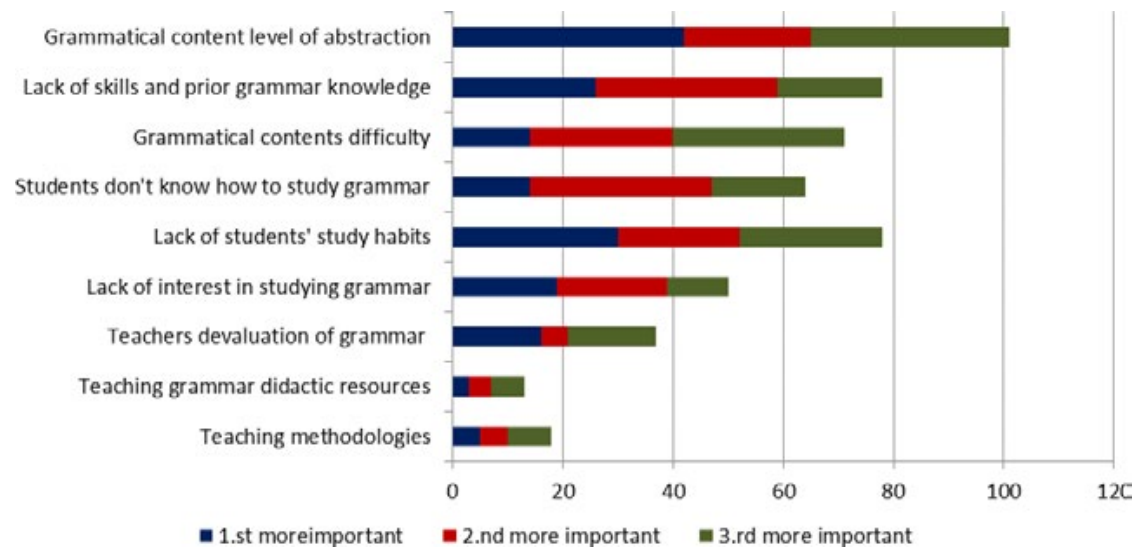

Figure 8. Identification of the three main reasons for students' difficulties experienced in grammar learning, according to primary school teachers

The fact that primary school professionals have different education plans when compared to their middle school colleagues plays a significant part in this perception. Being generally qualified for teaching language, mathematics, science and creative expression, primary school teachers are generalists and therefore receive less in-depth training in each of these areas, whereas most middle school teachers are professionalized only in the teaching of Portuguese, History and Geography. But the key point to be made from these data concerns how the teachers' responses highlight the role played by Specific Grammar Knowledge in the way they perceive their own grammar teaching. By adding this category of knowledge to the 'Knowledge Base map' consisting of teachers' perceptions that we constructed above, based on the analysis of the responses from 
middle school teachers, this finding also seems to us to corroborate, again from the perspective of teachers, Shulman's assumption about the role of this kind of knowledge in the act of grammar teaching. Primary school teachers perceived their lack of such knowledge as being critical for their activity, confirming that it is difficult for a teacher to teach certain content without mastering the corresponding scientific knowledge. This had not been so clear-cut in the former analysis.

This difference apart, both sets of teachers showed similar perceptions, in particular their perceived limitations regarding PCK and General Educational Knowledge. These seem to be at the core of present-day Portuguese teachers' perceptions regarding grammar teaching.

\section{Conclusions}

The main purpose of this study was to characterize Portuguese teachers' perceptions on their grammar knowledge and grammar teaching.

On the whole, our results showed that these teachers perceive grammar teaching to be important and appear to teach grammar with some frequency, unlike what appears to have been the case in the recent past. However, from what we could infer from our data, their Knowledge Base for grammar teaching shows some critical areas, especially regarding PCK, with particular emphasis on the importance of curriculum knowledge and instructional strategies, as well as General Educational Knowledge and (in the case of primary teachers) Specific Grammar Knowledge. These gaps in knowledge might be influencing the quality of their teaching practice, as we could infer from teachers' perceptions regarding the difficulties experienced by themselves and their students. Our results also support the idea that, in spite of official efforts to improve their knowledge of grammar teaching, in fact, teachers themselves perceive their training in this area to be still in need of considerable development.

As such, our data provides empirical support to Shulman's $(1986 ; 1987)$ model of Teachers' Knowledge Base and, in particular, to Grossman's (1990) adaptation of it, since the model has enabled us to gain a deeper understanding of the complexity of factors effectively involved in grammar teaching, as perceived by teachers themselves. Therefore, the data presented above point to the need to rethink the professional development of these school teachers with regard to their Knowledge Base for grammar teaching. We indeed believe that our results point towards possible directions both for initial and in-service teacher training which might be more contingent to what teachers themselves perceive to be pressing and necessary with regard to instruction in how to teach grammar in Portugal. In line with Watson's (2015) view of the English-speaking context, we believe that, in the Portuguese context too, weaknesses in teachers' scientific knowledge and the lack of a sufficiently theorized and empirically supported PCK, make grammar teaching particularly challenging for these professionals and improvements clearly need to be made. In addition, it seems urgent to provide a better General Educational Knowledge to raise teachers' social constructivist understanding and to prepare teachers to approach curricular instability in an autonomous and critical manner. This core knowledge set, which appears to be conditioning these teachers' professional practice, thus requires intervention. 
Our study is just a small and limited contribution to understanding (Portuguese teachers' perceptions of) the teaching of grammar. When looking at any aspect of a teaching activity (as this case study seeks to do) and given its multidimensional nature, it is necessary to resort to other methodologies of a diverse nature, triangulating, whenever possible, quantitative data with methodologies of a qualitative nature, such as observing teaching practice or conducting interviews. Given the constraints on our data collection context (a large number of respondents only available for a very short period of time), these more in-depth methodological approaches were excluded, and we decided to conduct a questionnaire survey despite such limitations. Although the study has allowed us to collect relevant data, the questionnaire that we designed did not, however, address any direct questions concerning perceptions about the purposes of teaching grammar or the context of teaching, two important categories in the Teachers' Knowledge Base model, therefore revealing limitations requiring further research. Furthermore, just as in any case study, our results, even if they are indeed representative of the perceptions of those teachers surveyed, should be taken only as exploratory.

Finally, our results also point to the need to conduct studies into grammar teaching practice in order to obtain a more reliable and provable characterization of the trends that we have identified.

\section{References}

Boivin, M.-C. 2018. A review of the current empirical research on grammar instruction in the francophone regions. Contribution to the special issue Working on Grammar at School in L1Education: Empirical Research across Linguistic Regions. L1 - Educational Studies in Language and Literature 17: 1-48.

Boivin, M.-C., Fontich, X., Funke, R. Folgado, M.-J. \& Myhill, D. 2018. Working on grammar at school in L1 education: Empirical research across linguistic regions. Introduction to the special issue Working on grammar at school in L1 education: Empirical research across linguistic regions. L1 - Educational Studies in Language and Literature 18: 1-6.

Buescu, H. C., Morais, J., Rocha, M. R \& Magalhães, V. F. 2015. Programa e metas curriculares de português do ensino básico [Programand Curriculum Goals for the Portuguese language]. Lisboa: Ministério da Educação e Ciência.

https://www.dge.mec.pt/sites/default/files/Basico/Metas/Portugues/pmcpeb_julho_2015. pdf (15 January 2019).

Buescu, H. C., Morais, J., Rocha, M. R. \& Magalhães, V. F. 2012. Metas curriculares de português: ensino básico. $1 .^{\circ}, 2^{\circ}$ e $3 .^{\circ}$ ciclos. [Portuguese Language Curriculum Goals for $1^{\text {st }}, 2^{\text {nd }}$ and $3^{\text {rd }}$ cycles]. Lisboa: Ministério da Educação e Ciência.

Chevallard, Y. 1985. La Transposition didactique: du savoir savant au savoir enseigné. Grenoble: La Pensée Sauvage.

Costa, J. \& Aguiar e Silva, V. (org.). (n.d.) Dicionário terminológico. [Terminological Dictionary] http://dt.dge.mec.pt/ (15 January 2019). 
Costa, J. 2007. Grammatical knowledge of the output of secondary education: current status and consequences in relation to reading, writing and speaking skills. In: C. Reis (org.) Proceedings of the CIEP. Lisboa: DGIDC - Ministério da Educação. 149-165.

DEB. 2001. Currículo Nacional do Ensino Básico - Competências Essenciais. [Basic Education Essential Skills]. Lisboa: Departamento da Educação Básica - Ministério da Educação. http:// www.cfaematosinhos.eu/NPPEB_01_CN.pdf. (15 January 2019).

DESPACHO n. ${ }^{\circ}$ 17169/2011. Diário da República, 2. a série N.o 245 de 23 de dezembro de 2011. p. 50080.

https://www.dge.mec.pt/sites/default/files/Basico/Legislacao/despacho_17169_2011.pdf(30 April 2017).

DGIDC. 2008. Posição dos docentes relativamente ao ensino da língua portuguesa.[Teachers' position regarding Portuguese language teaching]. Lisboa: Ministério da Educação, DGIDC.

http://www.dge.mec.pt/sites/default/files/Basico/Documentos/posicao_docentes_seminario. pdf](15 January 2019).

Duarte, I. 1986. O ensino da gramática: do imobilismo às modas. [Grammar Teaching: From Inaction to Current Trends]. Palavras 9: 38-42.

Duarte, I. 1998. Algumas boas razões para ensinar gramática. [Some good reasons to teach grammar.]. In: A língua mãe e a paixão de aprender. Actas. Porto: Areal, 110-123.

Duarte, I. 2000. Lingua Portuguesa: instrumentos de análise.[Portuguese Language: instruments of analysis.]. Lisboa: Universidade Aberta.

Ferreira, P. 2012. Conceções e práticas dos professores de língua portuguesa em relação ao ensino e à aprendizagem da gramática: um estudo exploratório no 2..$^{\circ}$ Ciclo do Ensino Básico [Concepts and practices of Portuguese language teachers in relation to grammar teaching and learning: an exploratory study at Middle School level.] Lisboa: Escola Superior de Educação de Lisboa: IPL. https://repositorio.ipl.pt/handle/10400.21/2321. (15 January 2019).

Grossman, P. 1990. The Making of a Teacher: Teacher Knowledge and Teacher Education. New York: Teachers College Press.

Milian, M. 2014. Working on grammar at school. In: T. Ribas, X. Fontich \& O. Guasch (eds.), Grammar at School - Research on Metalinguistic Activity in Language Education, 43-74. Brussels: Peter Lang S.A.

Myhill, D. 2018. Grammar as a meaning-making resource for improving writing. Contribution to a special issue Working on Grammar at School in L1-Education: Empirical Research across Linguistic Regions. L1 - Educational Studies in Language and Literature 18: 1-21. https://doi. org/10.17239/L1ESLL-2018.18.04.04_(15 January 2019).

Nespor, J. 1987. The Role of Beliefs in the Practice of Teaching. Journal of Curriculum Studies 19: 317-328.

Pereira, Í. , Viana, F. L. \& Silva, C.V. 2015. Sobre a formação do professor alfabetizador. Contributos para a caracterização do conhecimento de base do professor alfabetizador. [On literacy teacher 
training. Contributing factors in the knowledge base of literacy teachers]. Revista Perspectiva 33 (1): 231-259.

Reis, C. (coord.).2009. Programa de Português do Ensino Básico.[Program for Portuguese language teaching in Basic Education]. Lisboa: DGIDC - Ministério da Educação.

http://www.dge.mec.pt/sites/default/files/Basico/Metas/Portugues/programa_portugues_ revogado.pdf_(15 January 2019).

Roldão, M. do Céu. 2007. Função docente: natureza econstrução do conhecimento profissional. [Teaching: nature and construction of professional knowledge]. Revista Brasileira de Educação v. 12 (34): 94-103.

Shulman, L. S. 2004. The Wisdom of Practice: Essays on Teaching, Learning, and Learning to Teach. S. Wilson (ed.) San Francisco: Jossey-Bass, Inc.

Shulman, L. S. 1987. Knowledge and teaching: foundations of the new reform. Harvard Educational Review 57 (1): 1-22.

Shulman, L. S. 1986. Those who understand: Knowledge growth in teaching. Educational Researcher, Feb., 4-14.

Silva, C. V. 2008. O valor do conhecimento gramatical no ensino-aprendizagem da língua [The value of grammatical knowledge in language teaching and learning.]. Revista Saber (e) Educar 13: 89-106.

Silva, C. V. 2010. Para uma didáctica da gramática: a aula de Língua Portuguesa como um Laboratório de Língua. [Towards a grammar didactics: The Portuguese Language class as a Language Laboratory]. Textos selecionados do XXV Encontro Nacional da Associação Portuguesa de Linguística. Lisboa: APL, 717-732.

Silva, C. V. 2015. De Programa em Programa até às Metas Curriculares de Português: o desenho de percursos de aprendizagem na educação linguística. [From Programs to Curriculum Goals for the Portuguese language: learning pathway design for language teaching]. In: A. M. Ferreira, \& M. F. Brasete (eds.), Pelos Mares da língua portuguesa 2. Aveiro: UA Editora, 283-294.

Silva, C. V. \& Pereira, I. 2014. Do conhecimento gramatical ao conhecimento didático no ensino da Gramática: perceções de docentes do 1. ${ }^{\circ}$ Ciclo do Ensino Básico. [From grammatical knowledge to didactic knowledge in Grammar teaching: primary school teacher perceptions]. In: M.A. Flores, C. Coutinho \& J. A. Lencastre (org.), Atas do congresso Formação e trabalho docente na sociedade da aprendizagem. Braga: CIEC, 657-667.

Stake, R. 2000. Case Studies. In: N. K. Denzin, Lincoln, Yvonna S. (Ed.) Handbook of Qualitative Research, 134-164. Thousand Oaks, CA: Sage Publications, Inc.

Watson, A. 2015. The problem of grammar teaching: a case study of the relationship between a teacher's beliefs and pedagogical practice. Language and Education 29 (4): 332-346.

\section{Funding}

This work benefited from financial support by national funds provided by Foundation for Science and Technology (FCT/MCTES-PT). The first author was funded by CIEC (Center for Research in 
Child Studies at the University of Minho) project UID/CED/00317/2019. The second author was funded by CIEd - Research Centre on Education, project UID/CED/01661/2019, Institute of Education, University of Minho. The third author was funded by the Centre of Linguistics of the University of Porto, FCT UID/LIN/022/2016.

\section{$* * *$}

Cristina Vieira da Silva completed her PhD in Linguistics in 2003. She is currently a Coordinator Professor at the Higher School of Education of Paula Frassinetti in Porto and a member of CIEC (Research Centre on Child Studies) at the University of Minho. Her areas of research cover language teaching and learning, literacy education, reading, writing and grammar teaching.

Íris Susana Pires Pereira is a member of the Research Center on Education (CIEd) at the Institute of Education, University of Minho, in Portugal, where she holds the position of Assistant Professor of language and literacy education. Her research focuses on language and literacy learning in the early years, with a particular interest in the specialised forms of the language of schooling, now including digital resources for meaning making. She also investigates the role of specialized language in teachers' professional learning and development.

Isabel Sebastião is a post-doc researcher at the Centre of Linguistics of the University of Porto (CLUP) funded by a grant from the Foundation for Science and Technology. She has developed research work in discourse analysis and teaching of Portuguese language as mother tongue and foreign language. Isabel Sebastião has been sharing her research findings in articles published in scientific journals and in conference presentations in Portugal and abroad. 